\title{
Oxygenation in Anemic Newborn Lambs with High or Low Oxygen Affinity Red Cells
}

\author{
M. R. VAN AMERINGEN, J. C. FOURON, H. BARD, ${ }^{(22)}$ J. C. LE GUENNEC, AND J. PROSMANNE
}

Perinatal and Cardiology Services and Centre de Recherche Pediatrique De L'Hopital Sainte-Justine, Department of Pediatrics, University of Montreal, Montreal, Quebec, Canada

\begin{abstract}
Summary
Experiments to determine the effect of the oxygen-hemoglobin dissociation curve on oxygen delivery during neonatal anemia, were carried out on 15 sedated and ventilated lambs less than 48 hr of age. Eight of the animals were exchange transfused with adult blood. The $\mathbf{P}_{50}$ of the exchange transfused group was 32.1 $\mathrm{mm} \mathrm{Hg}$ (low $\mathrm{O}_{2}$ affinity) compared to $19.4 \mathrm{~mm} \mathrm{Hg}$ for the controls (high $\mathrm{O}_{2}$ affinity). The animals were made anemic by isovolumic exchange transfusions with plasma. At different levels of hemoglobin defined as mild $(8 \mathrm{mg} / 100 \mathrm{ml})$, moderate $(6 \mathrm{mg} / 100 \mathrm{ml})$, and severe $(4 \mathrm{mg} / 100 \mathrm{ml})$ anemia, tissue oxygenation, hemodynamic status, and blood gases were compared. Mixed venous $\mathbf{P O}_{2}$ was significantly lower in the high affinity group throughout the study. Cardiac output was significantly greater in the low affinity group during severe anemia. Oxygen consumption remained stable in the low affinity group, but decreased significantly in the high affinity group when the anemia was severe. The data indicate that during severe anemia, blood with a high $P_{50}$ is more capable of adequately oxygenating tissues than that with a low $\mathbf{P}_{50}$.
\end{abstract}

\section{Speculation}

Early preterm newborn infants may not adequately oxygenate their tissues during anemia because of their high oxygen affinity red cells.

An important adaptive mechanism during adult anemia is the shift to the right of the oxygen hemoglobin dissociation curve (15). Early preterm newborn infants have red cells with a relatively high oxygen affinity (3) and besides the numerous neonatal complications of prematurity these infants can also have a fall in hemoglobin level. It is apparent that a study was required to determine whether there could be obvious physiologic disadvantages of being anemic during a period of life when red cells have a high affinity for oxygen.

In order to answer this question, studies were planned using the newborn lamb, within the first $48 \mathrm{hr}$ of life, as an experimental model. The newborn lamb is born with a $P_{50}$ which is similar to that of an early preterm newborn infant $(18-19 \mathrm{~mm} \mathrm{Hg})(1)$ while the $P_{50}$ of the adult sheep blood is considerably higher $(30-38 \mathrm{~mm}$ $\mathrm{Hg}$ ) (10). This study was designed to compare at different degrees of anemia, tissue oxygenation, hemodynamic status as well as blood gases in newborn lambs with either high or low oxygen affinity red cells.

\section{MATERIALS AND METHODS}

Fifteen newborn lambs less than $48 \mathrm{hr}$ old were included in the study. Eight lambs containing high oxygen affinity red cells were considered as the high $\mathrm{O}_{2}$ affinity group and seven lambs who underwent a two volume exchange transfusion $(160 \mathrm{ml} / \mathrm{kg})$ using freshly drawn maternal blood made up the low oxygen affinity group. The animals were prepared in conformance with the guiding principles in the care and use of animals as recommended by the Declaration of Helsinki. They were first sedated enough to be kept asleep with repeated subcutaneous injections of Diazepam $(0.3 \mathrm{mg} / \mathrm{kg}$ every $20-30 \mathrm{~min})$. To eliminate sensibility to pain during catheter position, lidocaine hydrochloride $(2 \%)$ was used as a local anesthetic. Polyethylene catheters were then positioned, in the right atrium and the ascending aorta, using both a femoral vein and a femoral artery. Similarly using the remaining femoral vein a flow-dependent balloon catheter (Swan-Ganz 5F) was placed in the pulmonary artery. All animals were mechanically ventilated, after endotracheal intubation, by means of a Harvard animal respirator (Millis, MA) with the tidal volume and frequency adjusted so that the end-tidal $\mathrm{PCO}_{2}$ was $35 \pm 5 \mathrm{~mm} \mathrm{Hg}$. Temperature was kept constant at $38^{\circ} \mathrm{C} \pm 0.5$. Only as a means of insuring comparable constant metabolic conditions, they all received an intravenous injection of tubocurarine chloride $(0.3 \mathrm{mg} /$ $\mathrm{kg}$ ). A quarter of this initial dose was then repeated every $30 \mathrm{~min}$.

In order to produce a gradual isovolumic anemia in the two groups of animals, exchange transfusions were done with fresh plasma (obtained from sheep) reducing the hemoglobin level in $\mathrm{g} / 100 \mathrm{ml}$, in three progressive stages, firstly from the control level of 12 to 8 (mild anemia), then to 6 (moderate anemia), and finally to 4 (severe anemia). Before beginning the plasma exchange transfusion and $30 \mathrm{~min}$ after each stage of anemia, arterial and mixed venous $\mathrm{PO}_{2}, \mathrm{PCO}_{2}, \mathrm{pH}$, and oxygen hemoglobin saturations were monitored using a IL Blood Gas Laboratory 217 (Instrumentation Laboratories, Lexington, MA). Oxygen content was measured in duplicate samples from the aorta and pulmonary artery, using a Lex- $\mathrm{O}_{2}$-Con (Lexington Instrument Corporation, Waltham, MA). The accuracy of $\mathrm{O}_{2}$ content values measured directly on the Lex- $\mathrm{O}_{2}$-Con was checked with the calculated values based on the oxygen saturation obtained by the Co-Oximeter. In all instances they agreed within $0.2 \mathrm{vol} \%$. Throughout the study the difference between the $\mathrm{O}_{2}$ content of the pulmonary artery and the right atrium was never greater than $2 \%$, indicating that there was no left to right shunt through the ductus arteriosus.

The oxygen affinity was expressed as $\mathbf{P}_{50}$, the oxygen tension at which hemoglobin is half-saturated. This was determined on fresh blood samples equilibrated in a tonometer for $30 \mathrm{~min}$ at $37^{\circ} \mathrm{C}$, which permitted equilibration and sampling of successive aliquots of blood at different $\mathrm{O}_{2}$ tensions. Measurements of $\mathrm{O}_{2}$ saturation $\mathrm{pH}$ and $\mathrm{PO}_{2}$ provided the information for determining the $\mathrm{P}_{50}$ which was converted to $\mathrm{pH} 7.4$ with a Bohr effect of 0.46 (7). There were at least four experimental points for each oxygendissociation curve. The S.D. of the mean $\mathrm{P}_{50}$ obtained on the same blood sample was $0.76 \mathrm{~mm} \mathrm{Hg}(\mathrm{n}=11)$.

Aorta and pulmonary artery pressures were continuously recorded on a Grass model 7B Polygraph using a Statham strain gauge (P23Dc) transducer. To measure oxygen consumption, expired air was collected in a spirometer for a period of $3 \mathrm{~min}$. This procedure was repeated 7-8 times per animal and the S.D. of the minute-volume was always less than $2 \%$ of the mean. The oxygen concentration in the expired gas was measured directly using an 
oxygen analyser (model S-3A, Applied Electro-Chemistry Inc., Sunnyvale, CA).

The oxygen consumption $\left(\mathrm{V}_{2}\right)$ as well as all blood samples were studied in duplicate after each decrease in hematocrit level and from these data, the cardiac output of each animal was calculated using the Fick principle. Twelve normal newborn lambs were used to validate the measurements of $\mathrm{VO}_{2}$ obtained in this study. In these animals $\dot{\mathrm{VO}}_{2}$ was measured four times during an interval of $6 \mathrm{hr}$ and the results showed little variations (S.D. of the values was less than $5 \%$ of the mean).

The statistical test used to compare the mean data obtained in the study was the Student's two sample $t$ test. However when the difference in $\mathrm{V}_{2}$ within the same high $\mathrm{O}_{2}$ affinity group was evaluated (control level of hemoglobin versus severe anemia) a paired $t$ test was used. Hotelling's $\mathrm{T}^{2}$ multivariate analysis of tests (18) were used to compare the mean $\mathrm{V}_{2}$ obtained at the four levels of hemoglobin of both groups of animals. Also a nonparametric Mann-Whitney test (13) was used to check the normality assumption of the same data.

\section{RESULTS}

The results of these studies are expressed as mean and S.E. The control $\mathrm{pH}$ values for the high and low affinity groups were 8.394 \pm 0.034 and $7.438 \pm 0.037$, respectively. These $\mathrm{pH}$ values did not change significantly during the study. The mean $\mathrm{P}_{50}$ of each of the two groups of lambs at the control levels of hemoglobin were 19.4 $\pm 1.06 \mathrm{~mm} \mathrm{Hg}$ for the high oxygen affinity group and $32.1 \pm 2.5$ $\mathrm{mm} \mathrm{Hg}$ for the low oxygen affinity group respectively $(P<0.001)$. The $P_{50}$ values of each of the groups were unchanged at the end of the experiment $(20.4 \pm 0.8$ versus $32.7 \pm 2.8)$. The relative stability and similarity of the experimental preparation is demonstrated on Figure 1, where the arterial $\mathrm{PO}_{2}$ of both groups of animals is represented. There was no significant difference in the arterial $\mathrm{PO}_{2}$ of both groups of animals at the normal hemoglobin level as well as at any stage of anemia. However the mixed venous $\mathrm{PO}_{2}\left(\mathrm{P}_{\overline{\mathrm{V}}} \mathrm{O}_{2}\right)$ was significantly lower in the high oxygen affinity group at the control basal level $(P<0.01)$. As the level of hemoglobin decreased in both groups of animals the $\mathrm{PvO}_{2}$ de-

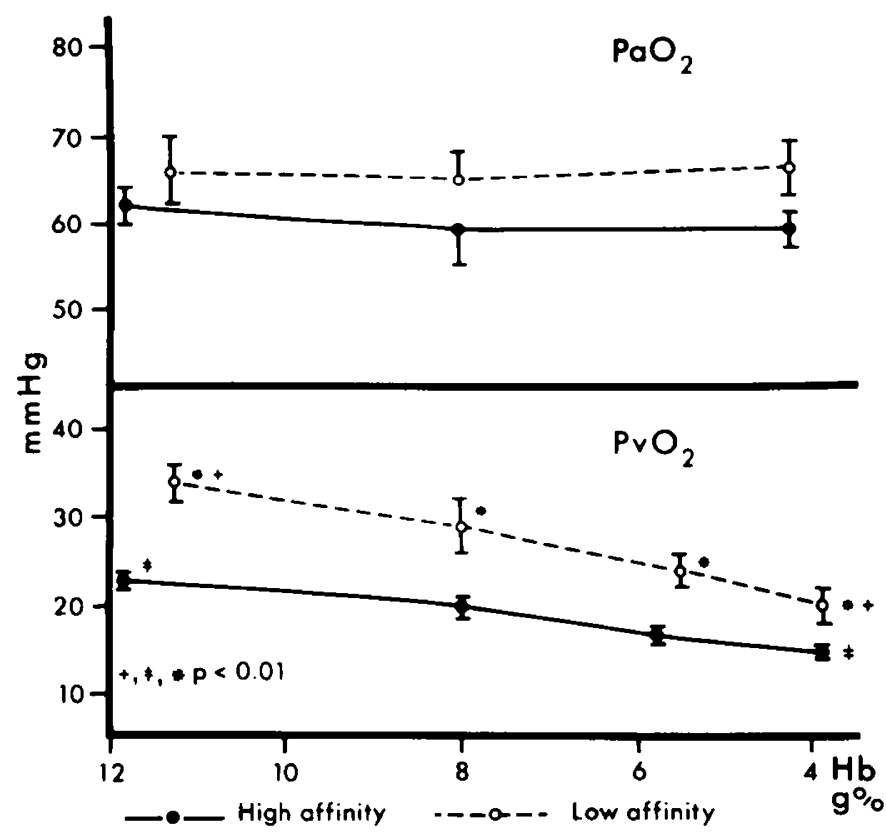

Fig. 1. The arterial and mixed venous $\mathrm{PO}_{2}$ during progressive anemia. The lines join the mean \pm S.E. of newborn lambs with either high affinity or low affinity red cells. The notations + and $\ddagger$ represent significant differences between control and anemic hemoglobin levels, while * indicates a significant difference between high and low affinity blood at all hemoglobin levels. creased concomitantly and the difference between both groups remained significant throughout the experiment. In severe anemia, the tissue $\mathrm{O}_{2}$ extraction increased. The percentages of $\mathrm{O}_{2}$ extraction augmented from 32 to $65 \%$ and from 39 to $63 \%$ for the high and low oxygen affinity group, respectively. The arterial blood content and mixed venous oxygen content diminished gradually and significantly $(P<0.01)$ as a result of the decrease in hematocrit (Fig. 2). The change was of the same magnitude in both groups of animals.

Under normal control hemoglobin levels there was no significant difference in stroke volume, heart rate, and cardiac output of both groups of animals (Fig. 3). During mild anemia there was an increase in heart rate. As the anemic became more severe both groups of newborn lambs developed bradycardia. Despite this initial rise in heart rate the stroke volume increased slowly. This change in stroke volume was significantly greater during the period of bradycardia (Fig. 3). When cardiac output was correlated to the degree of anemia it was found to increase more significantly in the low oxygen affinity group, while in the very severe anemic state it was more than twice that of the control condition. On the other hand, the cardiac output of the high oxygen affinity group rose slowly reaching a maximum of $6 \mathrm{~g}$ hemoglobin and then leveling off between 6 and $4 \mathrm{~g}$ hemoglobin.

The mean aortic blood pressures during progressive anemia can be seen in Figure 4 (top). There was no difference between the two groups of animals but during severe anemia there was a small decrease in mean arterial pressure in both groups. The pattern was similar with the pulmonary arterial pressures. When the systemic and pulmonary resistance was calculated, a great variability in individual values from one animal to the other was observed. However the mean values, although appearing greater in the high affinity group at all levels of anemia, was not significantly different (Fig. 4, bottom).

Figure 5 demonstrates the stability of $\dot{\mathrm{VO}}_{2}$ in the group of newborn lambs exchange transfused with adult blood, even during extreme anemia. However, in the high affinity group a comparable $\dot{\mathrm{VO}}_{2}$ was present only down to $6 \mathrm{~g} / 100 \mathrm{ml}$ hemoglobin. From then on, as the hemoglobin values decreased, oxygen consumption decreased to reach levels significantly lower than those found with

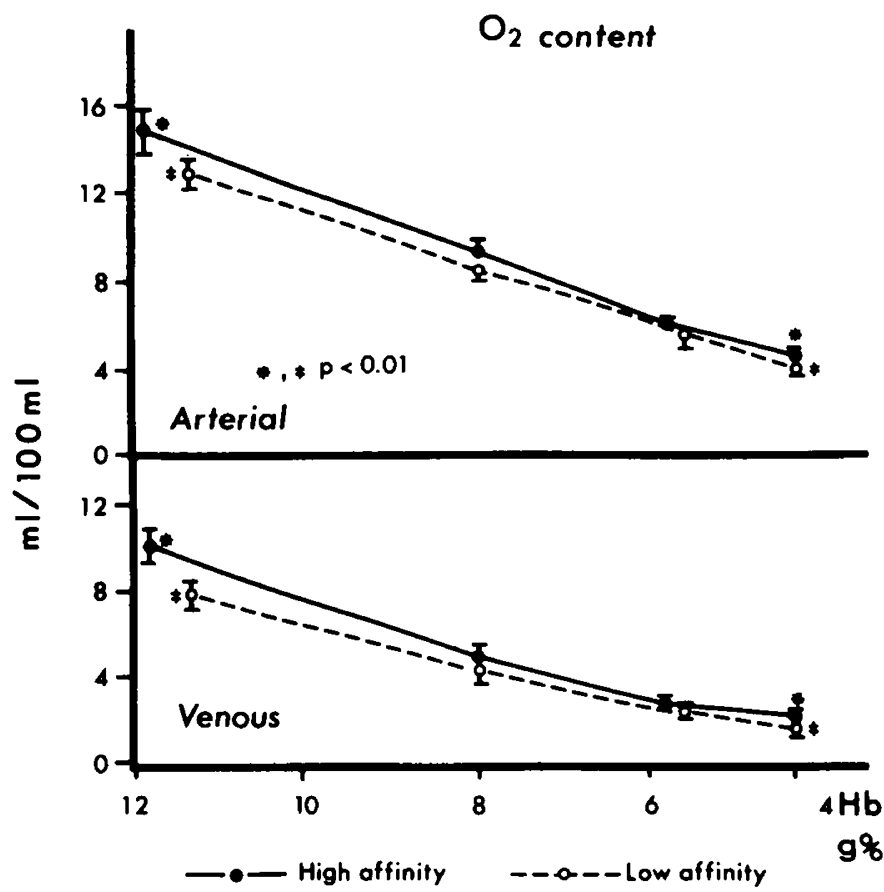

Fig. 2. The decline in arterial and venous blood oxygen content with progressive anemia, in newborn lambs with either high affinity or low affinity red cells. The lines join the mean \pm S.E. The notations * and $\ddagger$ represent significant differences between the hemoglobin levels in control and severe anemia. 


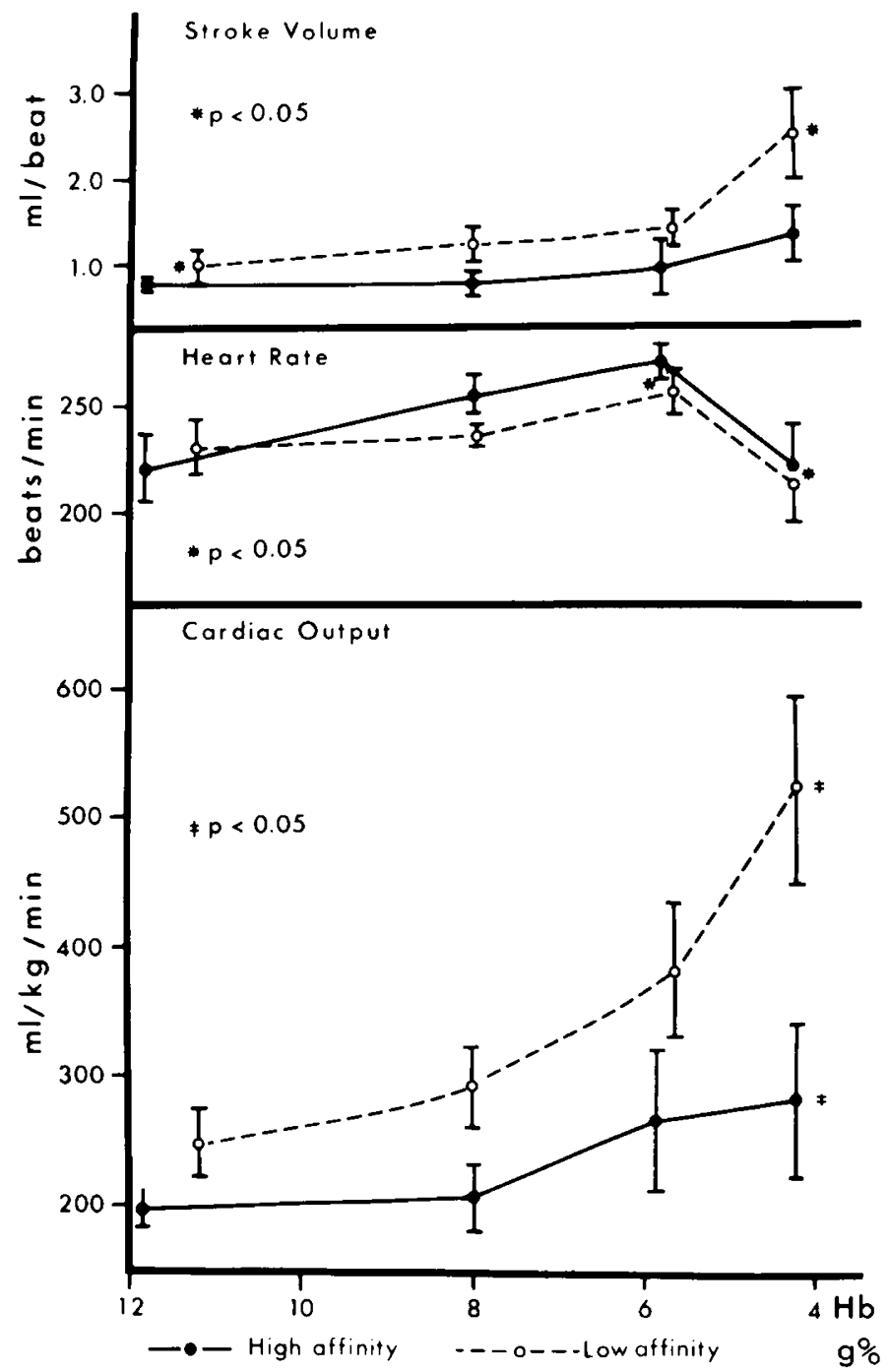

Fig. 3. The relationship of stroke volume, heart rate, and cardiac output to progressive anemia. The lines join the mean \pm S.E. of newborn lambs with either high affinity or low affinity red cells. The notation * indicates significant differences in values obtained at different hemoglobin levels and $\ddagger$ between the groups having high or low oxygen affinity blood.

adult red cells $(P<0.01)$. There was also a significant decrease of $\dot{\mathrm{V}}_{2}$ within the high $\mathrm{O}_{2}$ affinity group during severe anemia $(P$ $<0.005$ ).

In order to test the differences between the $\dot{\mathrm{V}}_{2}$ of the high $\mathrm{O}_{2}$ affinity group and the low $\mathrm{O}_{2}$ affinity group, Hotelling's $\mathrm{T}^{2}$ multivariate test (18) was used incorporating the four levels of hemoglobin. This test indicated that the overall $\mathrm{V}_{2}$ of the low $P_{50}$ group was lower than the high $P_{50}$ group $(P=0.0287)$. To determine what levels of anemia accounted for the difference, variance analysis (F tests) were carried out (18). The $\dot{\mathrm{VO}}_{2}$ differences at $6 \mathrm{~g} / 100 \mathrm{ml}$ hemoglobin gave a $P$ value of 0.08 (nonsignificant) and a significant $P$ value of 0.017 at the level of $4 \mathrm{~g} / 100$ $\mathrm{ml}$ hemoglobin. These last $\mathrm{F}$ tests were then checked for a possible departure from the normality assumption by the nonparametric Mann-Whitney test (13) and yielded $P$ values of 0.076 and 0.012 at 6 and $4 \mathrm{~g} / 100 \mathrm{ml}$ hemoglobin, respectively. Thus the above described treatment of the $\mathrm{VO}_{2}$ data confirmed that there was a significant decrease in $\dot{\mathrm{VO}}_{2}$ in the low $\mathrm{P}_{50}$ group during severe anemia.

\section{DISCUSSION}

Early preterm newborn infants undergo a decrease in their hemoglobin levels during the early weeks of life. During this period these infants are considered to have a refractory anemia and reach very low levels of hemoglobin before resumption of active erythropoiesis $(6,12)$. Thus infants born at less than $32 \mathrm{wk}$

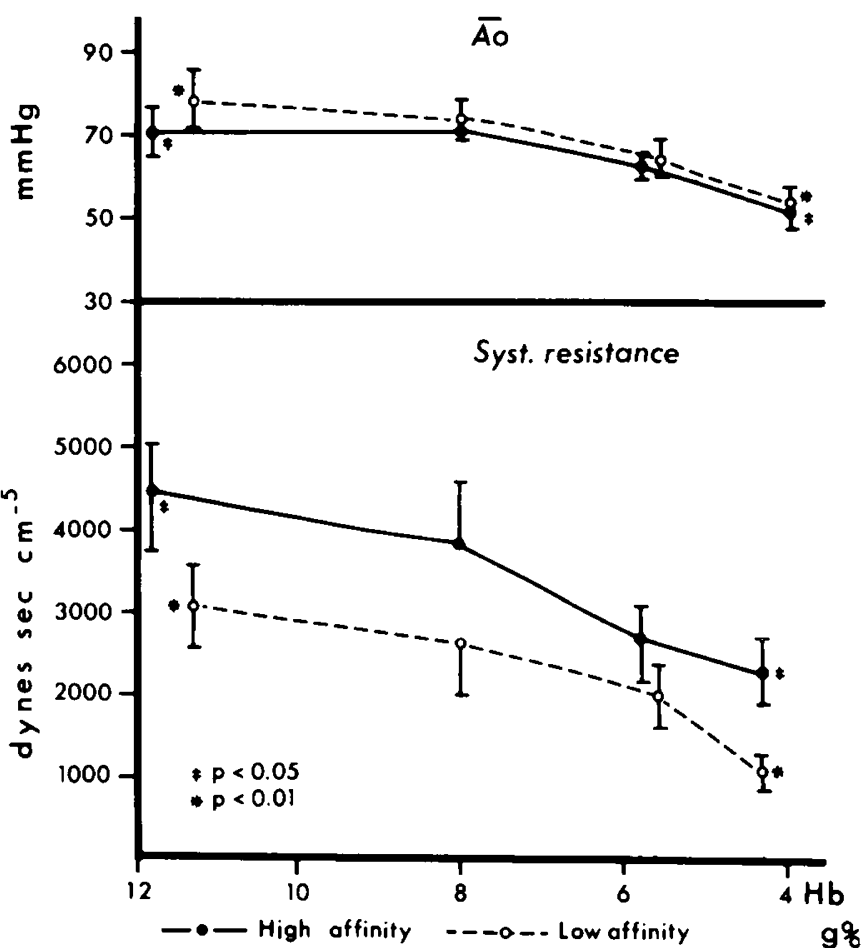

Fig. 4. The mean systemic arterial pressure and systemic resistance during progressive anemia with either high or low affinity red cells. The lines join the mean \pm S.E.

of gestation, at the time of their lowest hemoglobin concentration (3-11 wk after birth) have $P_{50}$ values much lower $(20.3 \pm 2.3 \mathrm{~mm}$ $\mathrm{Hg})(17)$ than what has been reported during adult anemia $(30.2$ $\pm 1.9 \mathrm{~mm} \mathrm{Hg}$ ) (15). In contrast, some newborn mammalian species that are used as experimental models, rapidly decrease their red cells oxygen affinity soon after birth $(1,2)$, so that when their postnatal decrease in hemoglobin concentration occurs their $\mathbf{P}_{50}$ levels are similar to the adult values (8). In this study an attempt was made to determine if the position of the oxygen-dissociation curve in newborn lambs with high oxygen affinity red blood cells would impair oxygen delivery to the tissues during increasing levels of anemia.

Previous studies $(4,16)$ have shown that tissue oxygenation, in presence of blood with high oxygen affinity and normal hematocrit, results in a lowering of $\mathrm{P}^{\mathrm{v}} \mathrm{O}_{2}$. In the present experiment, this was similarly observed at control hemoglobin levels. In severe anemia, since the cardiac output has been found to be significantly lower in the group with high affinity red cells compared to adult blood, an increase in the arteriovenous $\mathrm{O}_{2}$ content difference would be needed to maintain equivalent $\mathrm{O}_{2}$ delivery to the tissue. The fact that the arteriovenous $\mathrm{O}_{2}$ content difference did not increase resulted in the decrease in $\mathrm{O}_{2}$ consumption in the low $\mathrm{P}_{50}$ group during severe anemia.

An important factor responsible for this increase in systemic flow during anemia is most likely the decrease in blood viscosity $(5,9)$. In this study, peripheral resistance fell with anemia and showed a tendency to be greater (though not significantly) in presence of high $\mathrm{O}_{2}$ affinity red cells. This phenomenon could be one of the factors responsible for the lower cardiac output found in the high affinity group in severe anemia. Unfortunately the data collected in our study do not indicate whether the disparity in peripheral resistance and cardiac output between the two groups of animals was due to vasomotor or viscosity factors. In any case, according to accepted concepts (11), the hemodilution during the phases of moderate and severe anemia of these studies should have similarly improved the flow properties of the blood thus resulting in minimal rheological differences between the two groups of animals.

In our experiments, newborn animals having low oxygen affinity red cells had their arterial $\mathrm{O}_{2}$ content reduced by severe anemia to a point where $\mathrm{P}_{\mathrm{v}} \mathrm{O}_{2}$ was considered barely adquate for tissue 


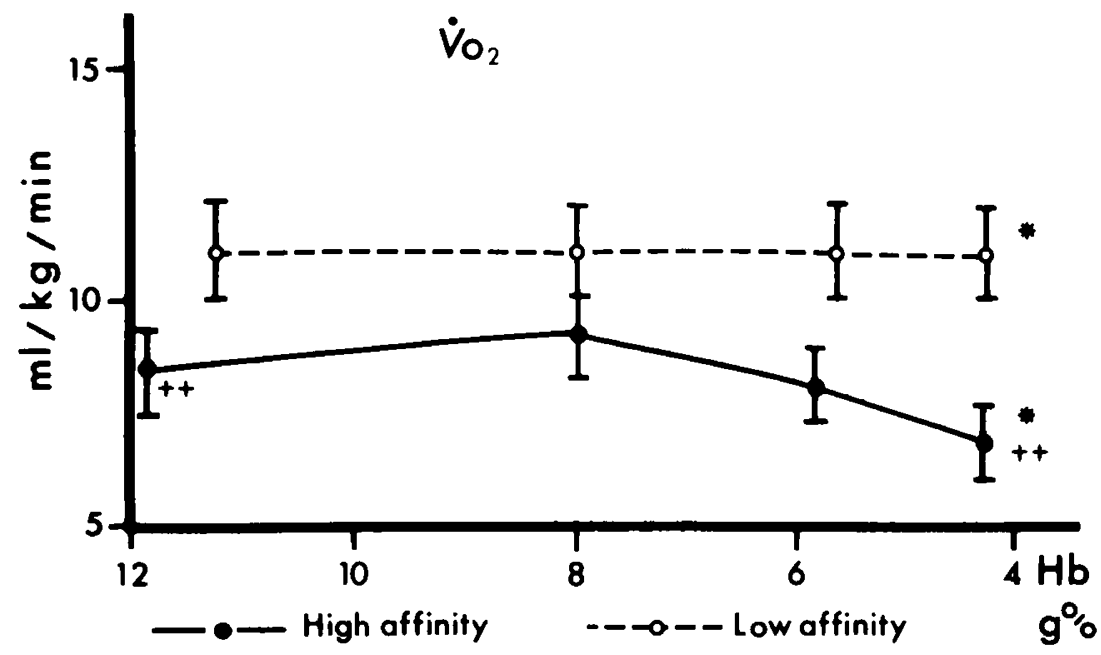

Fig. 5. The oxygen consumption of newborn lambs with either high affinity or low affinity red cells, in relation to anemia. The lines join the mean and \pm S.E. The notation * indicates a significant difference between the mean values obtained from the high and low oxygen affinity blood groups. The symbol ++ indicates a significant difference between the mean values obtained at the control hemoglobin level and severe anemia within the high oxygen affinity group.

oxygenation. Other newborn animals under the same conditions of severe anemia but having red cells with high oxygen affinity had an even greater decrease in their oxygen consumption which could indicate that an inadequate amount of oxygen was being delivered to their tissues. The recently completed study by Lister et al. (8) where nonsedated newborn lambs were evaluated as to oxygen delivery during the first 2 months of life, suggested that there exists a lower mixed venous $\mathrm{PO}_{2}$ in lambs which is close to some "cricital end-capillary $\mathrm{PO}_{2}$ " where cardiac output would have to increase out of proportion to meet tissue $\mathrm{O}_{2}$ demands. Although our study was confined to the newborn period and the experimental conditions were not the same, it is of interest to note that the critical low hemoglobin concentration speculated by Lister et al. (8) at $6 \mathrm{~g} / 100 \mathrm{ml}$, is similar to the hemoglobin value below which our data demonstrated a remarkable increase in cardiac output in the low affinity group as well as the decrease in $\mathrm{O}_{2}$ consumption in the newborn animals with high affinity red cells. As arterial $\mathrm{O}_{2}$ content dropped oxygen consumption was maintained in part, in the high $\mathbf{P}_{50}$ animals, by the increase in cardiac output.

It has been previously shown in a study of infants who were born prematurely, that at comparable levels of anemia, those having high amounts of fetal hemoglobin and thus increased hemoglobin oxygen affinity, manifested higher plasma erythropoietin activity than the infants with higher concentrations of adult hemoglobin and lower hemoglobin affinity (14). This finding led to the speculation that the ability to unload oxygen to the tissues during anemia of prematurely born infants is a function of the position of the oxygen-dissociation curve. The present experiments confirmed this point by demonstrating that in newborn lambs red cells with a high $P_{50}$ were more capable of adequately oxygenating tissues than red cells with low $P_{50}$ during severe anemia. While one cannot extrapolate directly to the early preterm newborn infant, it does suggest that the human premature infant may be at more of a physiologic disadvantage than an adult when oxygen carrying capacity of blood is decreased by anemia. This finding could be clinically important during the neonatal period.

\section{REFERENCES AND NOTES}

1. Bard, H., Fouron, J. C., Grothe, A. M., Soukini, M. A., and Cornet, A. The adaptation of the fetal red cells of newborn lambs to extrauterine life: The role of 2,3-diphosphoglycerate and adult hemoglobin. Pediatr. Res., 10: 823 (1976). 2. Bard, H., and Shapiro, M.: Perinatal changes of 2.3-diphosphoglycerate and oxygen affinity in mammals not having fetal type hemoglobins. Pediatr. Res., 13: 167 (1979).

3. Bard, H., and Teasdale, F.: Red cell oxygen affinity, hemoglobin type, 2,3diphosphoglycerate, and $\mathrm{pH}$ as a function of fetal development. Pediatrics, 64 : 483 (1979).

4. Fouron, J. C., Bard, H., Le Guennec, J. C., and Van Ameringen, M. R.: Effect of fetal or adult red cells on tissue oxygenation and myocardial function in normoxemic newborn lambs. Pediatr. Res., 15: 967 (1981).

5. Fowler, N. O., and Holmes, J. C.: Dextran-exchange anemia and reduction in blood viscosity in the heart-lung preparation. Am. Heart J., 68: 204 (1964)

6. Gairdner, D., Marks, J., and Roscoe, J. D.: Blood formation in infancy. Part IV. The early anemia of prematurity. Arch. Dis. Childh., 30: 203 (1955).

7. Hilpert, P., Fleischmann, R. G., Kempe, D., and Bartels, H.: The Bohr effect related to blood and erythrocyte pH. Am. J. Physiol., 205: 337 (1963).

8. Lister, G., Walter, T. K., Versmold, H. T., Dallman, P. R., and Rudolph, A. M.: Oxygen delivery in lambs: Cardiovascular and hematologic development. Am. J. Physiol., 237: H668 (1979).

9. Murray, J. F., and Escoban, E.: Circulatory effects of blood viscosity: Comparison of methemoglobinemia and anemia. J. Appl. Physiol., 25: 594 (1968).

10. Naughton, M. A., Meschia, G., Battaglia. F. C., Hellergers, A., Hagopian, H., and Barron, D. H.: Hemoglobin characteristics and the oxygen affinity of the bloods of dorset sheep. Quart. J. Exp. Physiol., 48: 313 (1963).

11. Schmid-Schönbein, H.: Microrheology of erythrocytes, blood viscosity, and the distribution of blood flow in the microcirculation. Cardiovascular Physiology II. pp. 1-62 (University Park Press. Baltimore. 1976).

12. Seip, M., and Halvorsen, S.: Erythrocyte production and iron stores in premature infants during the first months of life. Acta Paediatr. Scand. 45: 600 (1956)

13. Siegel, S.: Nonparametric Statistics for the Behavioral Sciences. pp. 116-127 (McGraw-Hill, New York, 1956).

14. Stockman, J. A., III, Garcia, J. F., and Oski, F. A.: The anemia of prematurity. N. Engl. J. Med.. 296: 647 (1977).

15. Torrance, J., Jacobs, P., Restrepo, A., Eschbach. J., Lenfant, C., and Finch, C. A.: Intraerythrocytic adaptation to anemia. N. Engl. J. Med., 283: 165 (1970).

16. Valeri, C R and Collins, F. B. The physiologic effect of 23-DPG depleted red cells with high affinity for oxygen. J. Appl. Physiol.. 31: 823 (1971).

17. Wardrop, C. A. J., Holland, B. M., Veale, K. E. A., Jones, J. G., and Gray, O. P.: Nonphysiological anaemia of prematurity. Arch. Dis. Childh., 53: 855 (1978).

18. Winer, B. J.: Statistical Principles in Experimental Design, 2nd ed. pp. 54-57 (McGraw-Hill, New York, 1971).

19. The authors thank Marie-Thérèse Rabeau, B.Sc. for her technical help and Nicole Nérette for her secretarial assistance.

20. This research was supported by Grant MA-5120 from the Medical Research Council of Canada.

21. Dr. M. R. Van Ameringen is Fellow of the Canadian Heart Foundation.

22. Requests for reprints should be addressed to: Harry Bard. Hôpital Ste Justine. 3175 Chemin Ste Catherine, Montreal Quebec Canada. H3TiC5

23. Received for publication February 3, 1981.

24. Accepted for publication May 11, 1981 